\title{
EFFECT OF SEEDLING AGE AND METHOD OF TRANSPLANTING ON THE YIELD OF AMAN RICE
}

\author{
T. K. Sarker'1, M. D. Hossain ${ }^{2}$, M. A. Salam ${ }^{3}$ and M. G. Rabbani ${ }^{4}$ \\ Department of Agronomy, Bangladesh Agricultural University \\ Mymensingh-2202, Bangladesh
}

\begin{abstract}
An experiment was conducted at the Agronomy Field Laboratory, Bangladesh Agricultural University, Mymensingh from June to December 2012 with a view to finding out the effect of seedling age and method of transplanting on the yield of Aman rice. Four seedling ages (10, 20, 30 and 40 days) and two transplanting methods (line and haphazard) were used as experimental treatments with four replications in a randomized complete block design. Seedling age, transplanting method and their interaction significantly influenced most of the yield components and yield of transplant Aman rice cv. BRRI dhan41. The highest total tillers, effective tillers hill-1 ${ }^{-1}$ grains panicle ${ }^{-1}$, grain yield, straw yield and harvest index were obtained from 30-day-old seedlings. Line transplanting method produced the highest total tillers, effective tillers hill ${ }^{-1}$, grain yield and harvest index. The highest total tillers, effective tillers hill-1-1, grain yield and harvest index were obtained from 30-day-old seedlings with line transplanting method. Results revealed that 30-dayold seedlings under line transplanting method could be used to obtain maximum yield of transplant Aman rice cv. BRRI dhan 41.
\end{abstract}

Key Words: Seedling age, Transplanting method, Yield, Transplant Aman rice

\section{INTRODUCTION}

Rice (Oryza sativa L.) is the staple food and major cereal crop of Bangladesh. It is the extensively cultivated crop for half of the world's population (FAO, 2010). It is grown throughout the year in the country, but the yield of this crop is low (HasanuzzAman et al., 2009). In Bangladesh transplant Aman rice contributes about $44.12 \%$ of the total rice production and covers $52.75 \%$ of the total rice area but the average yield is below the potential level (BBS, 2011). Age of seedling is an important factor to obtain higher yield of rice because it has tremendous influence on the tiller production, grain formation and other yield attributes. The use of over aged seedlings retards the general performance of crop and reduces the yield of crop (Bozorgi et al., 2011). For optimum yield, seedling age of a particular variety may not be suitable for other varieties. It is, therefore, needed to find out the optimum seedling age for recently introduced high yielding varieties of rice to produce higher yield.

\footnotetext{
1\&4Student Researcher, 2Associate Professor and 3Professor, Department of Agronomy, Bangladesh Agricultural University, Mymensingh-2202, Bangladesh
} 
Method of transplanting is another factor to be considered for rice cultivation. In main field, plant can be transplanted in two ways- transplanting in line and transplanting haphazardly. Transplanting in line is found better than transplanting haphazardly in terms of practicing intercultural operations and obtaining higher yield. On the other hand, haphazard transplanting requires less time and labour than that of transplanting in line (Ganajaxi et al., 2000). Therefore, it is necessary to examine not only seedling age but also transplanting method of Aman rice to ensure higher yield. The present research was, therefore, undertaken to determine the effects of seedling age and transplanting method on the yield of Aman rice.

\section{MATERIALS AND METHODS}

The experiment was conducted at the Agronomy Field Laboratory, Bangladesh Agricultural University, Mymensingh from June to December 2012. The land of the experimental area was medium high with moderate drained condition. The soil was silty loam in texture having a $\mathrm{pH}$ value of 6.43 , moderate in organic matter content (UNDP and FAO, 1988).

The experimental treatments consisted of two factors (A) four seedling ages, viz. (i) 10-dayold $\left(\mathrm{S}_{1}\right)$, (ii) 20-day-old $\left(\mathrm{S}_{2}\right)$, (iii) 30-day-old $\left(\mathrm{S}_{3}\right)$ and 40-day-old $\left(\mathrm{S}_{4}\right)$ and (B) two transplanting methods, viz. (i) transplanting in line $\left(\mathrm{M}_{1}\right)$ and (ii) haphazard transplanting $\left(\mathrm{M}_{2}\right)$. The experiment was laid out in a randomized complete block design with four replications. Treatment combinations were assigned at random in block. The unit plot size was $4.0 \mathrm{~m} \times 2.5 \mathrm{~m}$. BRRI dhan 41 was used as the test cultivar in the study. The land was well prepared to puddle condition. All weeds and stubbles were removed. The experimental plots were fertilized with urea, triple super phosphate, muriate of potash, gypsum and zinc sulphate @ 180, 100, 70,60, and $10 \mathrm{~kg} \mathrm{ha}^{-1}$, respectively. Seedlings were transplanted in line at the rate of two seedlings hill-1 maintaining a spacing of $25 \mathrm{~cm} \times$ $15 \mathrm{~cm}$, and the haphazard transplanting was done without spacing. Different intercultural operations were done as and when necessary.

The crop of each plot was harvested at maturity. Data on different plant characters were recorded from the five randomly selected hills in each plot and those on grain and straw yields were recorded from central $1 \mathrm{~m}^{2}$ area of each plot. The data were compiled and tabulated in proper form and subjected to statistical analysis. Analysis of variance was done with the help of computer package MSTAT-C program. The significant differences between individual means were performed using Duncan's Multiple Range Test (Gomez and Gomez, 1984).

\section{RESULTS AND DISCUSSION}

\section{Effect of seedling age}

There was significant difference in plant height due to the effect of seedling age (Table 1). The tallest plant $(126.26 \mathrm{~cm})$ was recorded from 40-day-old seedlings. The shortest plant $(122.18 \mathrm{~cm})$ was obtained from 10-day-old seedlings which was statistically identical with 
30-day-old seedlings. Significant variation in plant height was also observed due to variation in seedling age (Khatun et al., 2002). Seedling age had significant effect on number of total tillers hill-1. The highest number of total tillers hill-1 (10.62) was obtained from 30day-old seedlings. The lowest number of total tillers hill-1 (8.32) was obtained from 10-dayold seedlings. The result showed that younger seedlings produced less tillers than the older ones. Roy and Sattar (1992) reported similar findings observing less tiller number in younger seedlings compared to older ones. Number of effective tillers hill-1 varied significantly due to the age of seedlings. The highest number of effective tillers hill-1 (7.97) was observed from 30-day-old seedlings. The lowest number of effective tillers hill-1 (4.49) was produced from 10-day-old seedlings. Number of non-effective tillers hill-1 was influenced significantly by seedling age. The highest number of non-effective tillers hill-1 (3.83) was observed from 10-day-old seedlings. Thirty-day-old seedlings produced the

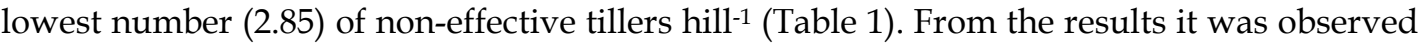
that younger seedlings produced more non-effective tillers hill-1 than the older ones.

It is observed that panicle length was significantly influenced by the age of seedlings (Table 1). Forty-day-old seedlings produced the longest panicle $(24.00 \mathrm{~cm})$ which was statistically at par with 20 and 30-day-old seedlings and the shortest one $(22.90 \mathrm{~cm})$ from 10 day-old seedlings. The effect of seedling age on grains panicle ${ }^{-1}$ was found significant. The highest number of grains panicle ${ }^{-1}$ (169.07) was obtained from 30-day-old seedling which was statistically identical with that of 40 -day-old seedlings. The lowest number of grains panicle $^{-1}$ (120.60) was obtained from 10-day-old seedlings. Seedling age had significant effect on the production of sterile spikelets panicle-1. The highest number of sterile spikelets panicle $^{-1}$ (30.79) was obtained from 10-day-old seedlings whereas the lowest number (23.04) was obtained from 30-day-old seedlings. Seedling age had significant effect on 1000-grain weight. The highest 1000-grain weight (27.21) was obtained from 40-day-old seedlings and the lowest one (26.12) from 10-day-old seedlings (Table 1).

Grain yield was significantly influenced by seedling age (Table 1). The highest grain yield $\left(5.10 \mathrm{t} \mathrm{ha}^{-1}\right)$ was obtained from 30 -day-old seedlings. The lowest grain yield $\left(3.95 \mathrm{t} \mathrm{ha}^{-1}\right)$ was obtained from 10-day-old seedlings. The highest grain yield obtained from 30-day-old seedlings might be attributed to the highest number of effective tillers hill-1, highest number of grains panicle ${ }^{-1}$, and lowest number of sterile spikelets panicle ${ }^{-1}$ in this treatment. The results showed that grain yield decreased with decreasing seedlings age from 30-day. Our results were in accordance with those of Khatun et al. (2002) and Alam et al. (2002), who reported decreasing grain yield with the decrease of seedling age. Seedling age had a significant effect on straw yield. The highest straw yield $\left(5.69 \mathrm{t} \mathrm{ha}^{-1}\right)$ was obtained from $40-$ day-old seedling which was statistically identical with

30-day-old seedlings. The lowest straw yield $\left(4.92 \mathrm{t} \mathrm{ha}^{-1}\right)$ was obtained from 10-day-old seedlings. Seedling age had significant effect on harvest index. The highest harvest index $(47.87 \%)$ was obtained from 30-day-old seedlings and the lowest harvest index (44.44\%) was found from 10-day-old seedlings (Table 1). 


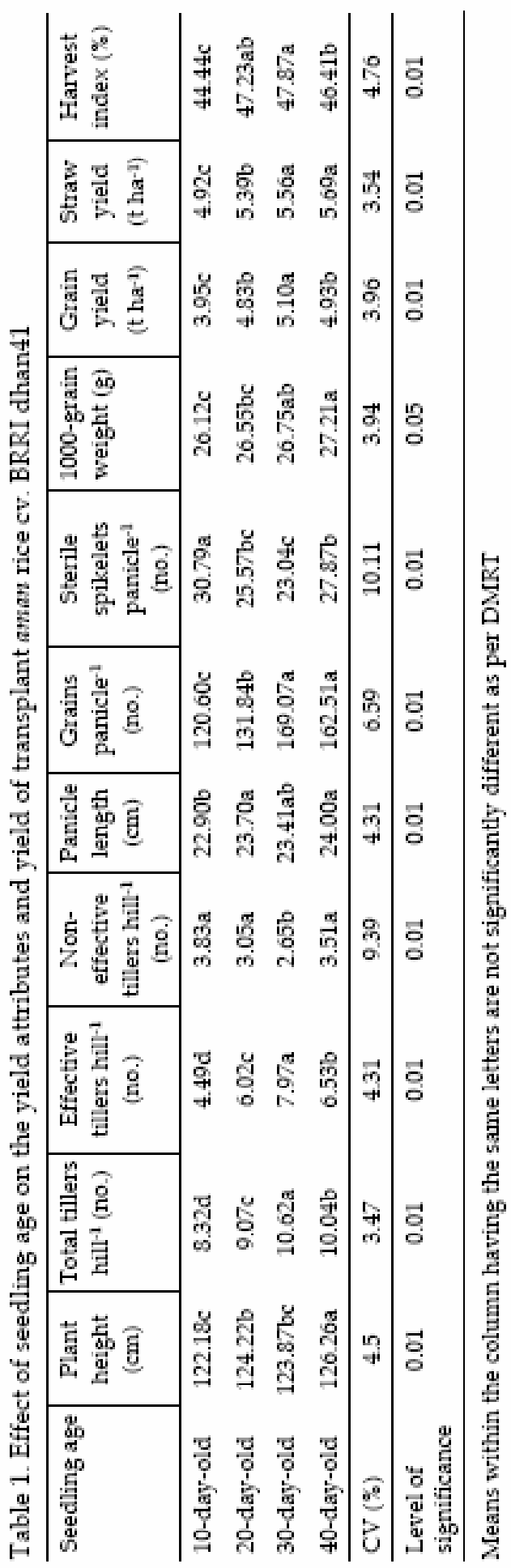




\section{Effect of transplanting method}

Plant height was significantly influenced by the transplanting methods (Table 2). The taller plant $(126.22 \mathrm{~cm})$ was found from transplanting in line and the shorter one $(122.05 \mathrm{~cm})$ from haphazard transplanting. Number of total tillers hill-1 was significantly influenced by transplanting method. Transplanting in line produced higher number of total tillers hill-1 (10.16) and the lower one (8.87) was produced from haphazard transplanting. Transplanting method had significant effect on number of effective tillers hill-1. The higher number of effective tillers hill-1 (6.63) was observed in line transplanting. The lower number of effective tillers hill-1 (5.88) was produced in haphazard transplanting. Transplanting method had significant effect on non-effective tillers hill-1. The higher number of non-effective tillers hill-1 (3.53) was observed under line transplanting method and the lower number of non-effective tillers hill-1 (2.99) was found under haphazard transplanting (Table 2).

Panicle length was significantly influenced by planting methods studied (Table 2). Haphazard transplanting produced the longer panicle $(23.76 \mathrm{~cm})$ and the lower one $(23.24$ $\mathrm{cm}$ ) was recorded from line transplanting method. Grains panicle ${ }^{-1}$ varied significantly by transplanting method. The higher grains panicle-1 (152.27) was found in haphazard transplanting and the lower one (139.74) was observed in line transplanting method. Sterile spikelets panicle ${ }^{-1}$ was significantly influenced by the method of transplanting. The higher number of sterile spikelets panicle-1 (29.88) was obtained from haphazard transplanting whereas the lower one (23.76) from line transplanting method (Table 2).

Transplanting method had significant effect on grain yield (Table 2). The higher grain yield (4.89 $\mathrm{t} \mathrm{ha}^{-1}$ ) was found from line transplanting method and the lower one $\left(4.51 \mathrm{t} \mathrm{ha}^{-1}\right)$ from haphazard transplanting method. The higher grain yield obtained from line transplanting might be due to higher number of effective tillers hill-1 and lower number of sterile spikelets panicle $^{-1}$ found in this treatment. Method of transplanting had significant effect on straw yield. The higher straw yield $\left(5.49 \mathrm{t} \mathrm{ha}^{-1}\right)$ was found from line transplanting and the lower straw yield (5.29 $\mathrm{t} \mathrm{ha}^{-1}$ ) from haphazard transplanting method. Harvest index varied significantly by transplanting method. The higher harvest index $(47.08 \%)$ was obtained from line transplanting method and the lower one $(45.89 \%)$ from haphazard transplanting method (Table 2).

\section{Interaction effect of seedling age and transplanting method}

The interaction between seedling age and transplanting method had significant effect on plant height (Table 3). The tallest plant $(128.97 \mathrm{~cm})$ was found from 40 -day-old seedlings under haphazard transplanting and the shortest one $(120.53 \mathrm{~cm})$ from 10-day-old seedlings under line transplanting method. Interaction between seedling age and transplanting method had significant effect on number of total tillers hill-1. The highest number (11.62) of total tillers hill ${ }^{-1}$ was obtained from 30-day-old seedlings under line transplanting method and the lowest one (8.57) was produced from haphazard transplanting of 20-day-old seedlings. Interaction between seedling age and transplanting method had significant effect on number of effective tillers hill-1. 


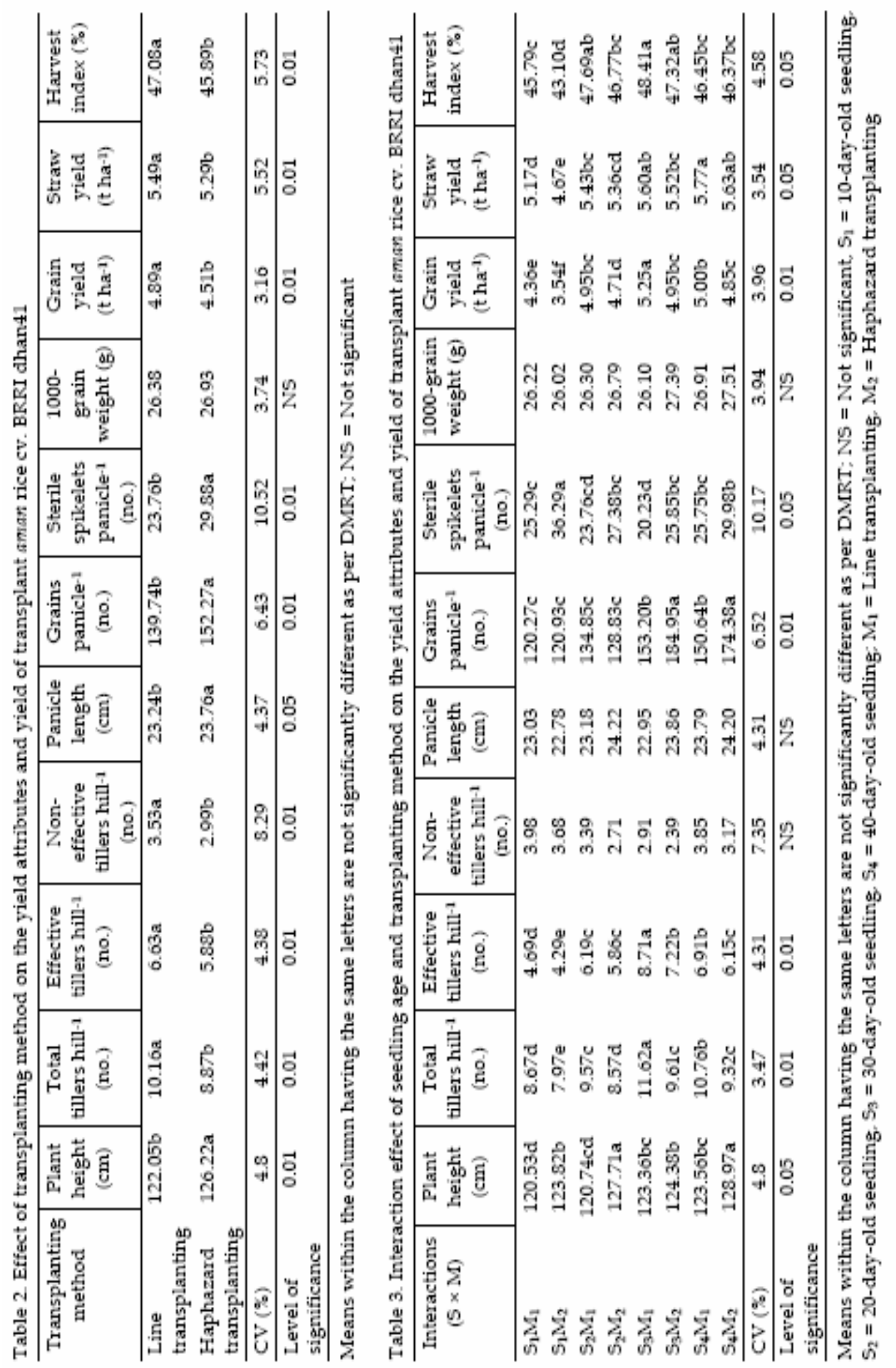


The highest number of effective tillers hill-1 (8.71) was observed from 30-day-old seedlings under line transplanting and the lowest number of effective tillers hill-1 ${ }^{-1}(4.29)$ was produced from 10-day-old seedlings under haphazard transplanting. Number of grains panicle ${ }^{-1}$ was significant by the interaction between seedling age and transplanting method. The highest number of grains panicle-1 (184.95) was observed from 30-day-old seedlings under haphazard transplanting. The lowest number of grains panicle ${ }^{-1}(120.27)$ was produced from 10-day-old seedlings under line transplanting. Interaction between seedling age and transplanting method had significant effect on number of sterile spikelets panicle-1. The highest number of sterile spikelets panicle ${ }^{-1}$ (36.29) was observed from 10-day-old seedlings under haphazard transplanting method. The lowest number of sterile spikelets panicle ${ }^{-1}$ (20.23) was produced from 30-day-old seedlings under line transplanting method (Table 3).

Interaction between seedling age and transplanting method had significant effect on grain yield (Table 3$)$. The highest grain yield $\left(5.25 \mathrm{t} \mathrm{ha}^{-1}\right)$ was observed from 30-day-old seedlings under line transplanting method. The lowest grain yield $\left(3.54 \mathrm{t} \mathrm{ha}^{-1}\right)$ was produced from 10day-old seedlings from haphazard transplanting method. Harvest index was significantly influenced by the interaction between seedling age and transplanting method. The highest harvest index $(48.31 \%)$ was observed from 30-day-old seedlings under line transplanting method. The lowest harvest index $(43.10 \%)$ was produced from 10-day-old seedlings under haphazard transplanting method (Table 3).

From the study, it is observed that yield attributes and yield of transplant Aman rice cv. BRRI dhan41 varied significantly due to variation in seedling age under different transplanting methods. It is revealed from the results that 30-day-old seedlings performed better under line transplanting method. In conclusion, it can be said that 30-day-old seedlings of BRRI dhan41 under line transplanting method could be used to attain higher yield.

\section{REFERENCES}

Alam, M. Z., Ahmed, M., Alam, M. S., Haque, M. E. amd Hossain, M. S. 2002. Performance of seedling ages and seedling raising techniques on yield and yield components of transplant amam rice. Pakistan J. Biol. Sci., 5(11): 1214-1216.

BBS (Bangladesh Bureau of Statistics). 2011. Monthly Statistical Bulletin, Bangladesh Stat. Div. Mins. Planning, Government, People's Republic of Bangladesh. Dhaka. p. 57.

Bozorgi, H. R., Faraji, A., Danesh, R. K., Keshovarz, A., Azarpour, E. and Tarighi, F. 2011. Effect of plant density on yield and yield components of rice. World applied Sci. J. 12(11): 2053-2057.

FAO (Food and Agriculture Organization), 1995. Production Year Book of 2010. No. 62. FAO, Rome, Italy. p. 54.

Ganajaxi, A. Argadi, V. V. and Rajkumara, S. 2000. Studies to develop appropriate techniques for growing direct seeded rice. Adv. Agril. Res., 13: 197-200.

Gomez, K. A. and Gomez, A. A. 1984. Statistical Procedure for Agricultural Research. $2^{\text {nd }}$ edn. John Wiley and Sons. New York. pp. 397-411. 
HasanuzzAman, M., RahAman, M. L., Roy, T. S., Ahmed, J. U. and Johaer, A. S. M. 2009. Plant characters, yield components and yield of late transplant Aman rice as affected by plant spacing and number of seedling per hill. Advances in Boil. Res., 3(5-6): 201-207.

Khatun, A., Mollah, M. I. U., Rashid, M. H., Islam, M. S. amd Khan, A. H. 2002. Seasonal effect of seedling age on the yield of rice. Pakistan J. Biol. Sci., 5(1): 40-42.

Roy, B. C. and Sattar, S. A. 1992. Tillering dynamics of transplanted rice as influenced by seedling age. Trop. Agric., 69(4): 18-21.

UNDP and FAO, 1988. Land Resources Appraisal of Bangladesh for Agricultural Development Report No. 2. Agro-ecological Regions of Bangladesh. United Nations Development Programme and Food and Agriculture Organization. pp. 213-226. 